\title{
Microbial Glycosylation of Daidzein, Genistein and Biochanin A: Two New Glucosides of Biochanin A
}

\author{
Sandra Sordon *, Jarosław Popłoński, Tomasz Tronina and Ewa Huszcza \\ Department of Chemistry, Wrocław University of Environmental and Life Sciences, Norwida 25, \\ 50-375 Wrocław, Poland; jaroslaw.poplonski@up.wroc.pl; (J.P.); tomasz.tronina@up.wroc.pl (T.T.); \\ ewa.huszcza@up.wroc.pl (E.H.) \\ * Correspondence: sandra.sordon@wp.pl; Tel.: +48-71-320-5197
}

Academic Editor: Derek J. McPhee

Received: 27 November 2016; Accepted: 30 December 2016; Published: 3 January 2017

\begin{abstract}
Biotransformation of daidzein, genistein and Biochanin A by three selected filamentous fungi was investigated. As a result of biotransformations, six glycosylation products were obtained. Fungus Beauveria bassiana converted all tested isoflavones to 4"-O-methyl-7-O-glucosyl derivatives, whereas Absidia coerulea and Absidia glauca were able to transform genistein and Biochanin A to genistin and sissotrin, respectively. In the culture of Absidia coerulea, in addition to the sissotrin, the product of glucosylation at position 5 was formed. Two of the obtained compounds have not been published so far: 4"-O-methyl-7-O-glucosyl Biochanin A and 5-O-glucosyl Biochanin A (isosissotrin). Biotransformation products were obtained with $22 \%-40 \%$ isolated yield.
\end{abstract}

Keywords: isoflavones; daidzein; genistein; Biochanin A; microbial glycosylation; fungi

\section{Introduction}

Isoflavones are the most well-known phytoestrogens [1]. They are secondary metabolites of the very restricted distribution in the plant kingdom, found exclusively in legumes (Leguminosae family). The major dietary sources of this most common form of phytoestrogens are soybeans, chickpeas and lentils [2]. Isoflavones have been implicated in the prevention of hormone-dependent diseases, such as: cancers (including breast, prostate and colon carcinoma) [3-6], cardiovascular disorders [7,8], bone health problems [9] and postmenopausal symptoms [10,11]. Therefore, there is considerable interest in the use of isoflavones in the prevention of estrogen-related cancers and certain diseases caused by estrogen deficiency.

Genistein and daidzein, the major isoflavones present in legumes, exist predominantly in the glycoside form, i.e., genistin and daidzin or 4'-methoxy derivatives, i.e., Biochanin A and formononetin, respectively [2].

Due to better solubility, greater stability and functionality compared to aglycones, glycosylated forms of flavonoids have recently been gaining increasing attention. Biotransformations of flavonoids is a useful tool to obtain their glycosylated derivatives. Application of microorganisms as biocatalysts allows us to obtain these compounds in sufficient amounts for research, e.g., the effect of a glycoside group on compound properties and for further application as ingredients of dietary supplements and pharmaceuticals [12].

The sugar moiety of flavonoids was proposed to be the major determinant of their absorption in humans [13]. It is generally believed that flavonoid glycosides are converted to the corresponding aglycones by the intestinal microflora and/or by the intestinal glucosidases, and as such absorbed from the small intestine [14]. Many studies have shown that flavonoid glycosides are poorly absorbed compared with their aglycones $[13,15,16]$. This phenomenon was partially revised recently as a result of studies on the bioavailability of flavonol quercetin. It turned out that quercetin-3-O- $\beta$-D-glucoside 
has higher bioavailability than its aglycone in humans, what suggests that conjugation with glucose would enhance quercetin absorption in the small intestine [17-19]. However, in the case of isoflavones, there are many evidences that aglycones have more biological effects than related glycosides, due to faster absorption in a greater amount $[20,21]$. These studies were focused on the most common isoflavone 7-O-glucosides, genistin and daidzin.

In this paper we described fungal biotransformation of three isoflavones: daidzein, genistein and Biochanin A. We found that substituents in the B-ring of tested flavonoids showed the impact on the regioselectivity of sugar moiety coupling.

\section{Results and Discussion}

Our previous research on microbial metabolism of flavonoids revealed that the fungal strains Beauveria bassiana AM 278, Absidia glauca AM 177 and Absidia coerulea AM 93 are able to attach sugar moiety to the chalcones and flavanones [22-24]. Therefore, biotransformation of daidzein, genistein and Biochanin A, the aglycones of the most commonly occurring isoflavones, using those microorganisms was investigated.

Screening tests have shown that genistein and Biochanin A were transformed by all of the tested strains, while daidzein was metabolized only by the fungus Beauveria bassiana. Experiments conducted on a larger scale enabled us to determine the chemical structure of the resulting products and their isolated yields (Figure 1).
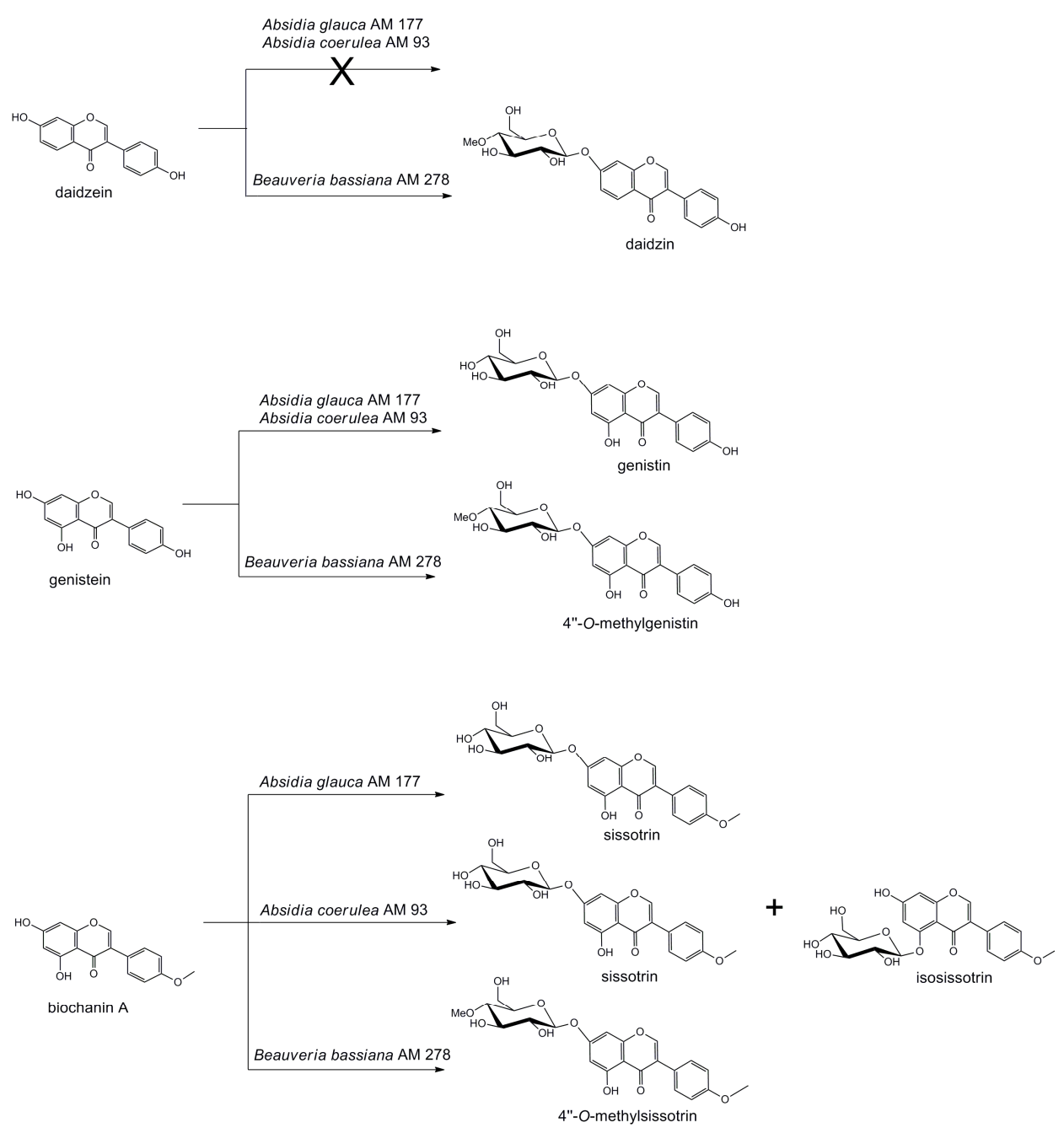

Figure 1. Transformation of isoflavonoids by selected fungi. 
Daidzein was converted to 4"-O-methyldaidzin by Beauveria bassiana with a yield of $33.3 \%$ ( $33.8 \mathrm{mg}$ ). This compound was earlier identified only in a soybean broth fermented by Paecilomyces militaris [25].

Genistein was metabolized by Absidia glauca and Absidia coerulea to genistin with a yield of $21.9 \%$ $(21.0 \mathrm{mg})$ and $12.5 \%(12.0 \mathrm{mg})$, respectively. Glucosylation at C-7 position of genistein was also observed for solvent-tolerant bacterium Staphylococcus saprophyticus CQ16 [26], as well as for plant cultured cells of Eucalyptus perriniana [27]. As it was expected based on our previous studies [22-24], fungus Beauveria bassiana transformed genistein to the typical for this species derivative-4"-O-methylgenistin (27.0 mg, 27.2\%).

Incubation of Biochanin A with Beauveria bassiana led to the new metabolite 4"-O-methylBiochanin A $(29.9 \mathrm{mg}, 30.8 \%)$. Seven proton and six carbon signals were observed in the regions from 3.21 to $5.03 \mathrm{ppm}$ in the ${ }^{1} \mathrm{H}-\mathrm{NMR}$ and from 60.9 to $101.5 \mathrm{ppm}$ in the ${ }^{13} \mathrm{C}-\mathrm{NMR}$ spectra. HSQC, HMBC and COSY spectra proved that the signals were corresponding to a glucose molecule. The methyl carbon $\left(\mathrm{C}-4{ }^{\prime \prime} \mathrm{OCH}_{3}\right)$ resonating at $\delta 60.9$ showed a one-bond correlation with three protons at $\delta 3.60$ on HMQC spectrum. These protons also showed three-bond correlation with carbon at $\delta 80.5$ (C4") on HMBC spectrum. Discussed metabolite had the molecular formula $\left(\mathrm{C}_{23} \mathrm{H}_{24} \mathrm{O}_{10}-\mathrm{H}\right)^{-}$as indicated by HR-ESIMS of the $[\mathrm{M}-\mathrm{H}]$-ion peak at $m / z 459.1297$ (calcd. 459.1296).

When Biochanin A was transformed by Absidia glauca as a bioreagent, the sissotrin was observed as the only product ( $38.0 \mathrm{mg}, 40.3 \%$ ). Glucosylation of Biochanin A at C-7 position was also performed by Absidia coerulea, however with a much lower yield ( $4.5 \mathrm{mg}, 4.6 \%)$. This phenomenon can be attributed to concurrent formation of the second metabolite, which was recognized as $5-O-\beta$-glucosylBiochanin A. The yield of this positional isomer of sissotrin, named isosissotrin by us, was $23.2 \%(22.5 \mathrm{mg})$. The composition of the products mixture was determined based on the NMR spectra analyses.

The NMR spectra of products obtained by biotransformation by Absidia coerulea AM 93 showed characteristic doubled signals (Figures S1-S12, Supplementary Materials). HMQC, HMBC and COSY experiments allowed us to establish unambiguously the flavonoid glycosides structure. The presence of doubled signals typical for a glucose moiety suggested the formation of two glucosylation products. In the ${ }^{1} \mathrm{H}-\mathrm{NMR}$ and ${ }^{13} \mathrm{C}-\mathrm{NMR}$ spectrum, doubled six proton and doubled six carbon signals corresponding to a glucose moiety structure were observed. The proton signal of $\mathrm{H}-1$ " of glucosylation product at C-5 position was overlapped with the artifact peak (likely of water) (Figures S1, S3, S5, S7, S8 and S10 Supplementary Materials).

Correlations observed in the HMBC spectrum permitted the assignment of the H-6 and H-8 protons of the two flavonoid products (Figure S9, Supplementary Materials). The aromatic A-ring protons $\mathrm{H}-6$ appearing as doublets at $\delta 6.83(\mathrm{~J}=2.2 \mathrm{~Hz})$ and $6.51(\mathrm{~J}=2.2 \mathrm{~Hz})$ resonated with three carbons (C-10: 110.3 ppm; C-5: 160.6 ppm; C-7: 164.7 ppm) and (C-10: 108.0 ppm; C-5: 163.5 ppm; C-7: $164.8 \mathrm{ppm}$ ) respectively. In turn, the other A-ring protons $\mathrm{H}-8$ appearing as doublets at $\delta 6.58$ $(J=2.2 \mathrm{~Hz})$ and $6.70(J=2.2 \mathrm{~Hz})$ resonated with four carbons (C-6: $104.5 \mathrm{ppm}$; C-10: $110.3 \mathrm{ppm}$; C-9: 160.9 ppm; C-7: 164.7 ppm) and (C-6: 101.2 ppm; C-10: 108.0 ppm; C-9: 159.2 ppm; C-7: $164.8 \mathrm{ppm})$, respectively.

The HMBC correlation between H-1" and C-7 and between H-1" and C-5 confirmed the location of sugar molecules. Noteworthy is that no significant signal shifts of both protons and carbons of the ring A of this product were observed, thus providing further confirmation of glucosyl moiety attachment. The glucose moieties were connected by 1,7-glycosidic linkages in sissotrin and by a 1,5-glycosidic linkage in isosissotrin (Figure S10, Supplementary Materials).

The products showed the [M - M]-ion peak at $m / z 445.1151$ (calcd. 445.1140) in HR-ESIMS. The exact molecular mass was consistent with a molecular formula of $\mathrm{C}_{22} \mathrm{H}_{22} \mathrm{O}_{10}$ and confirmed the formation of two positional isomers (Figure S13, Supplementary Materials).

Lewis et al. described the chemical synthesis of daidzin, genistin and sissotrin by the phase transfer catalyzed reaction between isoflavone aglycones of obtained products and 1-bromo-2,3,4,6-tetra-O-acetyl- $\alpha$-glucopyranose in the presence of tetrabutylammonium bromide as a catalyst [28]. This method has some disadvantages: the catalyst used in the reaction is harmful 
for the environment and the protection of hydroxyl groups that are not meant to conjugate with saccharide is necessary. Moreover, chemical synthesis does not solve the synthetic challenges of flavonoid 5-O-glucosides [29].

The use of filamentous fungi as a biocatalyst is the relevant method for obtaining isoflavonoid glucosides in simple and cheap one-step biotransformation process. Furthermore, according to the European Union Law, the products obtained by biotransformation are classified as natural compounds (EU Directive 88/388/EEC).

Summarizing, the course of the biotransformation of isoflavones by three selected filamentous fungi known from their ability to $O$-glycosylation was investigated. High regioselectivity maintaining low substrate specificity was observed in biotransformation conducted by Beauveria bassiana, which is typical for this species and has been shown in previous studies [22-24,30-32]. Whilst, the substrate specificity of enzymes from Absidia genus is higher. In the presented studies it was observed that isoflavones without a hydroxyl group at the C-5 position do not undergo biotransformation by Absidia species. In addition, presence of the methoxy group at C-4 $4^{\prime}$ position change the regioselectivity of biotransformations by Absidia coerulea, which may be associated with different substrate orientation in the catalytic pocket of the enzyme or with different enzyme catalyzing conversion of this substrates. Fungus Absidia coerulea glucosylates Biochanin A mainly at the 5-OH position, whereas Absidia glauca metabolizes Biochanin A only to one glucosylation product at the 7-OH position.

As we expected, the microorganisms used in the studies carried out conjugation of isoflavones with the sugar molecule. Daidzin and genistin occur naturally in relatively large amounts; however, sissotrin, isolated mainly from red clover, occurs in amounts more than 10-fold less than its aglycone form Biochanin A [33]. Therefore, our biotechnological methods of obtaining sissotrin as well as of isosissotrin may have practical significance. The fungal transformations presented in this article turned out to be a useful tool for obtaining new isoflavone glucosides as well as these, which naturally occur in small quantities. Due to relatively high yields (compared to chemical methods) the filamentous fungi biocatalysis can be used as a method of choice for bioavailability studies. There are many studies on bioavailability of genistein and its glucoside genistin and also daidzein and its glucoside daidzin, although absorption of isoflavonoid glycosides and their respective aglycones that form in humans is a subject of controversy [34]. Although there are reports in the literature on bioavailability of Biochanin A [35-37], there is no data about Biochanin A glucoside bioavailability, possibly due to the rarer occurrence of sissotrin in nature. Described biotransformation of Biochanin A is the method that allows us to obtain a glucoside in an amount sufficient for the research concerning the influence of glucose moiety on biological activity.

\section{Materials and Methods}

\subsection{Compounds}

Biochanin A (5,7-dihydroxy-4'-methoxyisoflavone) was purchased from Sigma-Aldrich (St. Louis, MO, USA). Daidzein (4',7-dihydroxyisoflavone) and genistein (4',5,7-trihydroxyisoflavone) were isolated from soy extract. Flavonoid glycosides included in the dry extract were hydrolyzed and the aglycones of daidzein and genistein were isolated from the reaction mixture according to the method described by Utkina et al. [38] and were of high purity ( $>98 \%$ by HPLC).

Daidzein: ${ }^{1} \mathrm{H}-\mathrm{NMR}\left(600 \mathrm{MHz}, \mathrm{DMSO}-d_{6}\right) \delta: 6.80\left(2 \mathrm{H}, \mathrm{m}, \mathrm{H}-3^{\prime}, \mathrm{H}-5^{\prime}\right), 6.85(1 \mathrm{H}, \mathrm{d}, J=2.2 \mathrm{~Hz}, \mathrm{H}-8), 6.93$ $(1 \mathrm{H}, \mathrm{dd}, J=8.7,2.2 \mathrm{~Hz}, \mathrm{H}-6), 7.37\left(2 \mathrm{H}, \mathrm{m}, \mathrm{H}-2^{\prime}, \mathrm{H}-6^{\prime}\right), 7.96(1 \mathrm{H}, \mathrm{d}, J=8.7, \mathrm{H}-5), 8.29(1 \mathrm{H}, \mathrm{s}, \mathrm{H}-2), 9.51$ $\left(1 \mathrm{H}, \mathrm{s}, 4^{\prime}-\mathrm{OH}\right), 10.77(1 \mathrm{H}, \mathrm{s}, 7-\mathrm{OH}){ }^{13} \mathrm{C}-\mathrm{NMR}\left(150 \mathrm{MHz}, \mathrm{DMSO}-d_{6}\right) \delta$ : 102.8 (C-8), 114.1 (C-6), 116.6 (C-10), $115.1\left(\mathrm{C}-3^{\prime}, \mathrm{C}-5^{\prime}\right), 122.5\left(\mathrm{C}-1^{\prime}\right), 123.5$ (C-3), 127.3 (C-5), 130.1 (C-2', C-6'), 152.8 (C-2), $157.2\left(\mathrm{C}-4^{\prime}\right)$, 157.4 (C-9), 162.5 (C-7), 174.7 (C-4).

Genistein: ${ }^{1} \mathrm{H}-\mathrm{NMR}\left(600 \mathrm{MHz}, \mathrm{DMSO}-d_{6}\right) \delta: 6.26(1 \mathrm{H}, \mathrm{d}, J=2.1 \mathrm{~Hz}, \mathrm{H}-6), 6.42(1 \mathrm{H}, \mathrm{d}, J=2.1 \mathrm{~Hz}, \mathrm{H}-8)$, $6.82\left(2 \mathrm{H}, \mathrm{m}, \mathrm{H}-3^{\prime}, \mathrm{H}-5^{\prime}\right), 7.37\left(2 \mathrm{H}, \mathrm{m}, \mathrm{H}-2^{\prime}, \mathrm{H}-6^{\prime}\right), 8.32(1 \mathrm{H}, \mathrm{s}, \mathrm{H}-2), 9.65\left(1 \mathrm{H}, \mathrm{s}, 4^{\prime}-\mathrm{OH}\right), 11.04(1 \mathrm{H}, \mathrm{s}$, 
7-OH), 12.94 (1H, s, 5-OH); ${ }^{13} \mathrm{C}-\mathrm{NMR}$ (150 MHz, DMSO-d 6 ) 8: 94.2 (C-8), 99.5 (C-6), 104.9 (C-10), 115.5 $\left(\mathrm{C}-3^{\prime}, \mathrm{C}-5^{\prime}\right), 121.4\left(\mathrm{C}-1^{\prime}\right), 122.7(\mathrm{C}-3), 130.6\left(\mathrm{C}-2^{\prime}, \mathrm{C}-6^{\prime}\right), 154.5$ (C-2), 157.9 (C-4'), 158.0 (C-9), 162.4 (C-5), 164.9 (C-7), 180.8 (C-4).

${ }^{1} \mathrm{H}$ - and ${ }^{13} \mathrm{C}-\mathrm{NMR}$ data were found to be identical to that of daidzein and genistein reported in the literature $[39,40]$.

\subsection{Biotransformation}

\subsubsection{Microorganisms}

The microorganisms used in this work, i.e., Beauveria bassiana AM 278, Absidia glauca AM 177 and Absidia coerulea AM 93, were obtained from the collection of the Department of Biology and Pharmaceutical Botany, Medical University of Wrocław, Poland.

\subsubsection{Screening Procedure}

All fermentation experiments were carried out in Sabouraud medium (D-glucose $30 \mathrm{~g}$ and peptone $10 \mathrm{~g}$ per liter of distilled water) on rotary shakers (130 rpm, 6.5 amplitude) at $28^{\circ} \mathrm{C}$. Agar slant cultures were used to obtain the inoculation culture. Portions of $0.5 \mathrm{~mL}$ of the 3-day inoculum were transferred to $100 \mathrm{~mL}$ Erlenmeyer flasks, each containing $30 \mathrm{~mL}$ of the medium. After cultivation, $5 \mathrm{mg}$ of a substrate dissolved in $0.5 \mathrm{~mL}$ of dimethyl sulfoxide (DMSO) was added to the grown culture and the reaction mixture was incubated for 7 days. After incubation the cultures were acidified with $1 \mathrm{M} \mathrm{HCl}$ to $\mathrm{pH}$ around 5 and extracted with ethyl acetate $(3 \times 15 \mathrm{~mL})$. The extracts were evaporated, and the residue dissolved in methanol and analyzed by TLC and HPLC. All experiments were performed with appropriate controls (the substrate in a sterile growth medium and incubation with no substrate).

\subsubsection{Preparative (Large) Scale Biotransformation}

Portions of $1.5 \mathrm{~mL}$ of the 3-day inoculation culture were transferred to $300 \mathrm{~mL}$ Erlenmeyer flasks, each containing $100 \mathrm{~mL}$ of the medium. In the preparative (large scale) biotransformation, a total of $60 \mathrm{mg}$ of each substrate dissolved in $6 \mathrm{~mL}$ of DMSO and was equally distributed among four flasks with 4-day fungal cultures to give a final concentration of $150 \mathrm{mg} / \mathrm{L}$. After 10 days of incubation, the cultures were acidified with $1 \mathrm{M} \mathrm{HCl}$ to $\mathrm{pH}$ around 5 and three time extracted with the same volume of ethyl acetate. The other procedures and culture conditions were the same as those of the screening experiments. The collected organic phase was dried over anhydrous $\mathrm{MgSO}_{4}$, the solvent was filtered, evaporated in a vacuum and analyzed using TLC and HPLC. The biotransformation products were separated by column chromatography on silica gel 60 (230-400 mesh, Merck, Darmstadt, Germany) using chloroform: methanol $(3: 1 \mathrm{v} / v)$ as eluent. TLC was carried out with Merck silica gel 60, $\mathrm{F}_{254}(0.2 \mathrm{~mm}$ thick) plates using the same eluents. Products were detected by inspecting plates under UV irradiation. $R_{\mathrm{f}}: 0.53$ (genistin); 0.64 (sissotrin, isosissotrin); 0.77 (4"-O-methyldaidzin); 0.79 (4"-O-methylgenistin); 0.84 (4"-O-methylsissotrin); 0.85 (genistein); 0.87 (daidzein); 0.89 (biochanin A).

\subsection{Analysis of Products with High Performance Liquid Chromatography (HPLC)}

HPLC was carried out on a Waters 2695 Alliance instrument with the photodiode array detector Waters 2996 (detection from 220 to $500 \mathrm{~nm}$ wavelength) using the analytical HPLC column Agilent C-18 ZORBAX Eclipse XDB $5 \mu \mathrm{m}(46 \mathrm{~mm} \times 250 \mathrm{~mm})$ at the flow rate of $1 \mathrm{~mL} / \mathrm{min}$ and injection volume $10 \mu \mathrm{L}$. A linear solvent gradient composed of $0.05 \%$ formic acid in water (A) and methanol containing $0.05 \%$ formic acid (B) was used. Chromatographic separation was achieved using the isocratic elution of $50 \% \mathrm{~A}$ and $50 \% \mathrm{~B}$ for $2 \mathrm{~min}$, then linear gradient of B from $50 \%$ to $95 \%$ for $10 \mathrm{~min}$ and isocratic elution of $95 \%$ B for $2 \mathrm{~min}$. RT (min): 3.79 (4"-O-methyldaidzin); 3.90 (genistin); 5.03 (4"-O-methylgenistin); 7.87 (daidzein); 8.51 (sissotrin); 8.82 (isosissotrin); 9.14 (genistein); 9.22 (4"-O-methylsissotrin); 12.15 (Biochanin A). 


\subsection{Identification of the Products}

Purified products were identified by NMR spectra analysis. ${ }^{1} \mathrm{H}-\mathrm{NMR},{ }^{13} \mathrm{C}-\mathrm{NMR},{ }^{1} \mathrm{H}-{ }^{1} \mathrm{H}-\mathrm{NMR}$ (COSY) and ${ }^{1} \mathrm{H}^{-13} \mathrm{C}-\mathrm{NMR}$ (HSQC, HMBC) were recorded on a DRX Bruker Avance TM $600(600 \mathrm{MHz})$ instrument. Negative-ion HR-ESIMS spectra were measured on a Bruker ESI-TOF Mass Spectrometer micrOTOF-Q. The direct infusion of ESI-MS parameters: The mass spectrometer was operated in negative ion mode with the potential between the spray needle and the orifice $4,5 \mathrm{kV}$, nebulizer pressure of $0.4 \mathrm{bar}$, and a drying gas flow rate of $4 \mathrm{~L} / \mathrm{min}$ at $200{ }^{\circ} \mathrm{C}$. The sample flow rate was $180 \mu \mathrm{L} / \mathrm{min}$. Ionization mass spectra were collected at the ranges $m / z$ 150-3000. The instrument was calibrated with an Agilent electrospray calibration solution (ESI-L low concentration Tuning Mix-Agilent Technologies, Agilent Product Number: G1969-85000) that was diluted with acetonitrile.

\subsection{Obtained Biotransformation Products}

7-O- $\beta$-D-4"-O-Methyl-glucopyranosyl-4'-hydroxyisoflavone (4"-O-methyldaidzin), (biocatalyst: Beauveria bassiana AM 278, yield: 33.3\%): ${ }^{1} \mathrm{H}-\mathrm{NMR}\left(600 \mathrm{MHz}, \mathrm{DMSO}-d_{6}\right) \delta: 3.06\left(1 \mathrm{H}, \mathrm{m}, \mathrm{H}-4^{\prime \prime}\right), 3.31(1 \mathrm{H}, \mathrm{m}$, H-2"), $3.45\left(1 \mathrm{H}, \mathrm{m}, \mathrm{H}-3^{\prime \prime}\right), 3.47\left(3 \mathrm{H}, \mathrm{s}, 4^{\prime \prime}-\mathrm{OCH}_{3}\right) 3.50$ (1H, m, Ha-6"), $3.52\left(1 \mathrm{H}, \mathrm{m}, \mathrm{H}-5^{\prime \prime}\right), 3.65(1 \mathrm{H}, \mathrm{m}$, Hb-6"), $4.75\left(1 \mathrm{H}, \mathrm{m}, 6^{\prime \prime}-\mathrm{OH}\right), 5.13\left(1 \mathrm{H}, \mathrm{d}, J=7.8 \mathrm{~Hz}, \mathrm{H}-1^{\prime \prime}\right), 5.32\left(1 \mathrm{H}, \mathrm{d}, J=5.5 \mathrm{~Hz}, 3^{\prime \prime}-\mathrm{OH}\right), 5.52$ $\left(1 \mathrm{H}, \mathrm{d}, J=5.3 \mathrm{~Hz}, 2^{\prime \prime}-\mathrm{OH}\right), 6.82\left(2 \mathrm{H}, \mathrm{m}, \mathrm{H}-3^{\prime}, \mathrm{H}-5^{\prime}\right), 7.14(1 \mathrm{H}, \mathrm{dd}, J=2.3 ; 8.9 \mathrm{~Hz}, \mathrm{H}-6), 7.22(1 \mathrm{H}, \mathrm{d}$, $J=2.3 \mathrm{~Hz}, \mathrm{H}-8), 7.40\left(2 \mathrm{H}, \mathrm{m}, \mathrm{H}-2^{\prime}, \mathrm{H}-6^{\prime}\right), 8.05(1 \mathrm{H}, \mathrm{d}, J=8.9 \mathrm{~Hz}, \mathrm{H}-5), 8.38(1 \mathrm{H}, \mathrm{s}, \mathrm{H}-2), 9.56(1 \mathrm{H}, \mathrm{s}$, $\left.4^{\prime}-\mathrm{OH}\right) ;{ }^{13} \mathrm{C}-\mathrm{NMR}\left(150 \mathrm{MHz}, \mathrm{DMSO}-d_{6}\right) \delta: 60.2\left(\mathrm{C}-6^{\prime \prime}\right), 73.3\left(\mathrm{C}-2^{\prime \prime}\right), 75.7\left(\mathrm{C}-5^{\prime \prime}\right), 59.7\left(\mathrm{C}-4^{\prime \prime} \mathrm{OCH}_{3}\right), 76.2$ (C-3"), 78.9 (C-4"), 99.6 (C-1") 103.3 (C-8), $115.0\left(\mathrm{C}-3^{\prime}, 5^{\prime}\right), 115.5$ (C-6), 118.5 (C-10), $122.3\left(\mathrm{C}-1^{\prime}\right), 123.7$ (C-3), 127.0 (C-5), $130.1\left(\mathrm{C}-2^{\prime}, 6^{\prime}\right), 153.4$ (C-2), 157.0 (C-9), $157.3\left(\mathrm{C}-4^{\prime}\right), 161.3(\mathrm{C}-7), 174.8(\mathrm{C}-4) .{ }^{1} \mathrm{H}-\mathrm{and}$ ${ }^{13} \mathrm{C}-\mathrm{NMR}$ data were found to be identical to that reported in the literature [25].

7-O- $\beta$-D-Glucopyranosyl-5,4'-dihydroxyisoflavone (genistin), (biocatalysts: Absidia coerulea AM 93, yield: 12.5\%; Absidia glauca AM 177, yield: 21.9\%): ${ }^{1} \mathrm{H}-\mathrm{NMR}\left(600 \mathrm{MHz}, \mathrm{DMSO}-d_{6}\right) \delta: 3.17\left(1 \mathrm{H}, \mathrm{m}, \mathrm{H}-4^{\prime \prime}\right), 3.26$ (1H, m, H-2"), 3.30 (1H, m, H-3"), $3.44\left(1 \mathrm{H}, \mathrm{m}, \mathrm{H}-5^{\prime \prime}\right), 3.47$ (1H, m, Ha-6"), 3.71 (1H, m, Hb-6"), 4.61 $\left(1 \mathrm{H}, \mathrm{m}, 6^{\prime \prime}-\mathrm{OH}\right), 5.06\left(1 \mathrm{H}, \mathrm{d}, J=7.5 \mathrm{~Hz}, \mathrm{H}-1^{\prime \prime}\right), 5.08\left(1 \mathrm{H}, \mathrm{m}, 4^{\prime \prime}-\mathrm{OH}\right), 5.15\left(1 \mathrm{H}, \mathrm{m}, 3^{\prime \prime}-\mathrm{OH}\right), 5.41(1 \mathrm{H}, \mathrm{m}$, 2"-OH), $6.47(1 \mathrm{H}, \mathrm{d}, J=2.2 \mathrm{~Hz}, \mathrm{H}-6), 6.72(1 \mathrm{H}, \mathrm{d}, J=2.2 \mathrm{~Hz}, \mathrm{H}-8), 6.83\left(2 \mathrm{H}, \mathrm{m}, \mathrm{H}-3^{\prime}, \mathrm{H}-5^{\prime}\right), 7.40(2 \mathrm{H}, \mathrm{m}$, H-2' ${ }^{\prime}$ H-6 $\left.{ }^{\prime}\right), 8.43(1 \mathrm{H}, \mathrm{s}, \mathrm{H}-2), 9.63\left(1 \mathrm{H}, \mathrm{s}, 4^{\prime}-\mathrm{OH}\right), 12.94(1 \mathrm{H}, \mathrm{s}, 5-\mathrm{OH}) ;{ }^{13} \mathrm{C}-\mathrm{NMR}\left(150 \mathrm{MHz}, \mathrm{DMSO}-d_{6}\right)$ 8: 60.6 (C-6"), 73.1 (C-2"), 76.4 (C3"), 69.6 (C-4"), 77.2 (C-5"), 94.5 (C-8), 99.6 (C-6), 99.8 (C-1"), 106.1 (C-10), $115.1\left(\mathrm{C}-3^{\prime}, 5^{\prime}\right), 121.0\left(\mathrm{C}-1^{\prime}\right), 122.6$ (C-3), 130.2 (C-2' , 6'), 154.6 (C-2), 157.2 (C-9), 157.5 (C-4'), $161.6(\mathrm{C}-5), 163.0(\mathrm{C}-7), 180.5(\mathrm{C}-4) .{ }^{1} \mathrm{H}-$ and ${ }^{13} \mathrm{C}-\mathrm{NMR}$ data were found to be identical to that reported in the literature $[41,42]$.

7-O- $\beta$-D-4"-O-Methyl-glucopyranosyl-5,4'-dihydroxyisoflavone (4"-O-methylgenistin) (biocatalyst: Beauveria bassiana AM 278, yield: 27.2\%): ${ }^{1} \mathrm{H}-\mathrm{NMR}\left(600 \mathrm{MHz}, \mathrm{DMSO}-d_{6}\right) \delta: 3.0\left(1 \mathrm{H}, \mathrm{m}, \mathrm{H}-4^{\prime \prime}\right), 3.27(1 \mathrm{H}$, m, H-2"), $3.44\left(1 \mathrm{H}, \mathrm{m}, \mathrm{H}-3^{\prime \prime}\right), 3.46\left(3 \mathrm{H}, \mathrm{s}, 4^{\prime \prime}-\mathrm{OCH}_{3}\right) 3.49\left(1 \mathrm{H}, \mathrm{m}, \mathrm{Ha}-6^{\prime \prime}\right), 3.52\left(1 \mathrm{H}, \mathrm{m}, \mathrm{H}-5^{\prime \prime}\right), 3.63(1 \mathrm{H}$, m, Hb-6"), $4.73\left(1 \mathrm{H}, \mathrm{m}, 6^{\prime \prime}-\mathrm{OH}\right), 5.09\left(1 \mathrm{H}, \mathrm{d}, J=7.8 \mathrm{~Hz}, \mathrm{H}-1^{\prime \prime}\right), 5.30\left(1 \mathrm{H}, \mathrm{d}, J=5.5 \mathrm{~Hz}, 3^{\prime \prime}-\mathrm{OH}\right), 5.48(1 \mathrm{H}$, $\left.\mathrm{d}, J=5.2 \mathrm{~Hz}, 2^{\prime \prime}-\mathrm{OH}\right), 6.47(1 \mathrm{H}, \mathrm{d}, J=2.2 \mathrm{~Hz}, \mathrm{H}-6), 6.71(1 \mathrm{H}, \mathrm{d}, J=2.2 \mathrm{~Hz}, \mathrm{H}-8), 6.83\left(2 \mathrm{H}, \mathrm{m}, \mathrm{H}-3^{\prime}, \mathrm{H}-5^{\prime}\right)$, $7.40\left(2 \mathrm{H}, \mathrm{m}, \mathrm{H}-2^{\prime}, \mathrm{H}^{\prime} 6^{\prime}\right), 8.43(1 \mathrm{H}, \mathrm{s}, \mathrm{H}-2), 9.62\left(1 \mathrm{H}, \mathrm{s}, 4^{\prime}-\mathrm{OH}\right), 12.94(1 \mathrm{H}, \mathrm{s}, 5-\mathrm{OH}) ;{ }^{13} \mathrm{C}-\mathrm{NMR}(150 \mathrm{MHz}$, DMSO- $\left.d_{6}\right) \delta$ : $59.7\left(\mathrm{C}-4^{\prime \prime}-\mathrm{OCH}_{3}\right), 60.2\left(\mathrm{C}-6^{\prime \prime}\right), 73.2\left(\mathrm{C}-2^{\prime \prime}\right), 75.7\left(\mathrm{C}-5^{\prime \prime}\right), 76.1\left(\mathrm{C} 3^{\prime \prime}\right), 78.9\left(\mathrm{C}-4^{\prime \prime}\right), 94.5(\mathrm{C}-8)$, $99.4\left(\mathrm{C}-1^{\prime \prime}\right), 99.5(\mathrm{C}-6), 106.1(\mathrm{C}-10), 115.1\left(\mathrm{C}-3^{\prime}, 5^{\prime}\right), 121.0\left(\mathrm{C}-1^{\prime}\right), 122.6(\mathrm{C}-3), 130.2\left(\mathrm{C}-2^{\prime}, 6^{\prime}\right), 154.6$ (C-2), 157.2 (C-9), 157.5 (C-4'), 161.7 (C-5), 162.9 (C-7), 180.5 (C-4). ${ }^{1} \mathrm{H}$ - and ${ }^{13} \mathrm{C}-\mathrm{NMR}$ data were found to be identical to that reported in the literature $[25,30]$.

7-O- $\beta$-D-Glucopyranosyl-5-hydroxy-4'-methoxyisoflavone (sissotrin), (biocatalysts: Absidia coerulea AM 93, yield: 4.6\%; Absidia glauca AM 177, yield: $40.3 \%):{ }^{1} \mathrm{H}-\mathrm{NMR}\left(600 \mathrm{MHz}, \mathrm{CD}_{3} \mathrm{OD}\right) \delta: 3.44-3.48(1 \mathrm{H}$, m, H-4"), 3.47-3.51 (1H, m, H-2"), 3.71-3.74 (1H, m, Ha-6"), $3.83\left(3 \mathrm{H}, \mathrm{s}, 4^{\prime}-\mathrm{OCH}_{3}\right), 3.90-3.93(1 \mathrm{H}, \mathrm{m}$, Hb-6"), $5.05\left(1 \mathrm{H}, \mathrm{m}, \mathrm{H}-1^{\prime \prime}\right), 6.51(1 \mathrm{H}, \mathrm{d}, J=2.2 \mathrm{~Hz}, \mathrm{H}-6), 6.70(1 \mathrm{H}, \mathrm{d}, J=2.2 \mathrm{~Hz}, \mathrm{H}-8), 6.98(2 \mathrm{H}, \mathrm{pd}$, $\left.J=8.7 \mathrm{~Hz}, \mathrm{H}-3^{\prime},{\mathrm{H}-5^{\prime}}^{\prime}\right), 7.48\left(2 \mathrm{H}, \mathrm{pd}, J=8.7 \mathrm{~Hz}, \mathrm{H}-2^{\prime}, \mathrm{H}^{\prime} 6^{\prime}\right), 8.16(1 \mathrm{H}, \mathrm{s}, \mathrm{H}-2) ;{ }^{13} \mathrm{C}-\mathrm{NMR}(150 \mathrm{MHz}$, $\left.\mathrm{CD}_{3} \mathrm{OD}\right)$ 8: $55.8\left(\mathrm{C}-4^{\prime} \mathrm{OCH}_{3}\right), 62.4\left(\mathrm{C}-6^{\prime \prime}\right), 71.2\left(\mathrm{C}-4^{\prime \prime}\right), 74.7\left(\mathrm{C}-2^{\prime \prime}\right), 77.8\left(\mathrm{C}-3^{\prime \prime}\right), 78.4\left(\mathrm{C}^{\prime \prime}\right), 95.9(\mathrm{C}-8)$, 
101.2 (C-6), 101.6 (C-1"), 108.0 (C-10), 114.9 (C-3', C-5'), 124.3 (C-1'), 124.8 (C-3), 131.3 (C-2', C-6'), 155.5 (C-2), 159.2 (C-9), 161.3 (C-4'), 163.5 (C-5), 164.8 (C-7), 182.4 (C-4). ${ }^{1} \mathrm{H}-$ and ${ }^{13} \mathrm{C}-\mathrm{NMR}$ data were found to be identical to that reported in the literature [43]. HRESI-MS [M $-\mathrm{H}]^{-}$(calculated/found) $(m / z 445.1140 / 445.1151)$.

5-O- $\beta$-D-Glucopyranosyl-7-hydroxy-4'-methoxyisoflavone (isosissotrin), (biocatalyst: Absidia coerulea AM 93, yield: 23.2\%): ${ }^{1} \mathrm{H}-\mathrm{NMR}\left(600 \mathrm{MHz}, \mathrm{CD}_{3} \mathrm{OD}\right)$ 8: 3.40-3.44 (1H, m, H-4"), 3.41-3.51 (2H, m, H-3", H-5"), 3.60-3.68 (1H, m, H-2"), 3.74-3.77 (1H, m, Ha-6"), $3.82\left(3 \mathrm{H}, \mathrm{s}, 4^{\prime}-\mathrm{OCH}_{3}\right), 3.93-3.96\left(1 \mathrm{H}, \mathrm{m}, \mathrm{H}-6 \mathrm{~b}^{\prime \prime}\right)$, $4.86\left(1 \mathrm{H}\right.$, signal obscured by water, $\left.\mathrm{H}-1^{\prime \prime}\right), 6.58(1 \mathrm{H}, \mathrm{d}, J=2.2 \mathrm{~Hz}, \mathrm{H}-8), 6.83(1 \mathrm{H}, \mathrm{d}, J=2.2 \mathrm{~Hz}, \mathrm{H}-6)$, $6.95\left(2 \mathrm{H}, \mathrm{pd}, J=8.7 \mathrm{~Hz}, \mathrm{H}-3^{\prime}, \mathrm{H}-5^{\prime}\right), 7.42\left(2 \mathrm{H}, \mathrm{pd}, J=8.7 \mathrm{~Hz}, \mathrm{H}-2^{\prime}, \mathrm{H}-6^{\prime}\right), 8.02(1 \mathrm{H}, \mathrm{s}, \mathrm{H}-2) ;{ }^{13} \mathrm{C}-\mathrm{NMR}$ $\left(150 \mathrm{MHz}, \mathrm{CD}_{3} \mathrm{OD}\right)$ 8: $55.7\left(\mathrm{C}-4^{\prime} \mathrm{OCH}_{3}\right), 62.5\left(\mathrm{C}-6^{\prime \prime}\right), 71.2\left(\mathrm{C}-4^{\prime \prime}\right), 74.7\left(\mathrm{C}-2^{\prime \prime}\right), 77.3\left(\mathrm{C}-3^{\prime \prime}\right), 78.6\left(\mathrm{C}-5^{\prime \prime}\right)$, 98.9 (C-8), 104.5 (C-6), 104.9 (C-1"), 110.3 (C-10), 114.7 (C-3', C-5'), 125.5 (C-1'), 126.7 (C-3), 131.6 (C-2', C-6' $), 153.3$ (C-2), 160.6 (C-5), 160.9 (C-9), 161.1 (C-4'), 164.7 (C-7), 178.1 (C-4). HRESI-MS [M - H] ${ }^{-}$ (calculated/found) $(\mathrm{m} / \mathrm{z} 445.1140 / 445.1151)$.

7-O- $\beta$-D-4"-O-Methyl-glucopyranosyl-5-hydroxy-4'-methoxyisoflavone (4"-O-methylsissotrin), (biocatalyst: Beauveria bassiana AM 278, yield: 30.8\%): ${ }^{1} \mathrm{H}-\mathrm{NMR}\left(600 \mathrm{MHz}, \mathrm{CD}_{3} \mathrm{OD}\right) \delta: 3.21\left(1 \mathrm{H}, \mathrm{m}, \mathrm{H}-4^{4 \prime}\right), 3.46-3.53$ $\left(2 \mathrm{H}, \mathrm{m}, \mathrm{H}-2^{\prime \prime}, \mathrm{H}-5^{\prime \prime}\right), 3.60\left(1 \mathrm{H}, \mathrm{m}, \mathrm{H}-3^{\prime \prime}\right), 3.60\left(3 \mathrm{H}, \mathrm{s}, 4^{\prime \prime}-\mathrm{OCH}_{3}\right), 3.72(1 \mathrm{H}, \mathrm{m}, \mathrm{Hb}-6 "), 3.83(3 \mathrm{H}, \mathrm{s}$, $\left.4^{\prime}-\mathrm{OCH}_{3}\right), 3.87\left(1 \mathrm{H}, \mathrm{m}, \mathrm{Ha}-6^{\prime \prime}\right), 5.03$ (1H, d, J = 7.7 Hz, H-1"), 6.52 (1H, m, H-6), 6.70 (1H, m, H-8), 6.99 $\left(2 \mathrm{H}, \mathrm{m}, \mathrm{H}-3^{\prime}, \mathrm{H}-5^{\prime}\right), 7.49\left(2 \mathrm{H}, \mathrm{m}, \mathrm{H}-2^{\prime}, \mathrm{H}-6^{\prime}\right), 8.17(1 \mathrm{H}, \mathrm{s}, \mathrm{H}-2) ;{ }^{13} \mathrm{C}-\mathrm{NMR}\left(150 \mathrm{MHz}, \mathrm{CD}_{3} \mathrm{OD}\right) \delta: 55.8$ $\left(\mathrm{C}-4^{\prime} \mathrm{OCH}_{3}\right), 60.9\left(\mathrm{C}-4^{\prime \prime} \mathrm{OCH}_{3}\right), 62.0\left(\mathrm{C}-6^{\prime \prime}\right), 74.8\left(\mathrm{C}-2^{\prime \prime}\right), 77.4\left(\mathrm{C}-5^{\prime \prime}\right), 77.9\left(\mathrm{C} 3^{\prime \prime}\right), 80.5\left(\mathrm{C}-4^{\prime \prime}\right), 95.9$ (C-8), 101.1 (C-6), 101.5 (C-1"), $108.1(\mathrm{C}-10), 115.0\left(\mathrm{C}-3^{\prime}, 5^{\prime}\right), 124.4\left(\mathrm{C}-1^{\prime}\right), 124.9$ (C-3), $131.4\left(\mathrm{C}-2^{\prime}, 6^{\prime}\right), 155.5$ (C-2), 157.3 (C-9), 161.4 (C-4'), 163.6 (C-5), 164.8 (C-7), 182.4 (C-4). HRESI-MS [M - H] ${ }^{-}$(calculated/found) $(m / z$ 459.1296/459.1297).

\section{Conclusions}

The aim of this paper was to develop a simple and efficient method for the preparation isoflavonoid glycosides, which can serve as analytical standards or model compounds for various biological tests.

All the microorganisms that we used performed conjugation of isoflavones with the sugar molecule. Fungi Absidia glauca AM 177 and Absidia coerulea AM 93 attached glucose, while the fungus Beauveria bassiana AM 278 4-O-methylglucose. With one exception, the preferred site of glycosylation was the C-7 hydroxyl group of substrates. Thus, as a result of glucosylation of genistein and Biochanin A, we obtained genistin and sissotrin, respectively. In the culture of fungi Absidia coerulea, Biochanin A was converted to a new derivative with glucose residue at the $\mathrm{C}-5$ position. To our best knowledge, this compound has not been published so far. The product of the biotransformation of Biochanin A by Beauveria bassiana AM 278 is also reported for the first time.

Supplementary Materials: Supplementary materials can be accessed at: http:/ /www.mdpi.com/1420-3049/21/ $1 / 81 /$ s1.

Acknowledgments: Publication supported by Wrocław Centre of Biotechnology, programme the Leading Notional Research Centre (KNOW) for years 2014-2018.

Author Contributions: Ewa Huszcza and Sandra Sordon conceived and designed the experiments; Sandra Sordon performed the experiments; Jarosław Popłoński analyzed the data and interpreted the NMR spectra; Tomasz Tronina isolated the isoflavonoids from soy extract; Sandra Sordon and Ewa Huszcza wrote the paper.

Conflicts of Interest: The authors declare no conflict of interest.

\section{References}

1. Adlercreutz, H. Phytoestrogens: Epidemiology and a possible role in cancer protection. Environ. Health Perspect. 1995, 103, 103-112. [CrossRef] [PubMed]

2. Wang, H.J.; Murphy, P.A. Isoflavone content in commercial soybean foods. J. Agric. Food Chem. 1994, 42, 1666-1673. [CrossRef] 
3. Kennedy, A.R. Prevention of carcinogenesis by protease inhibitors. Cancer Res. 1994, 54, 1999-2005.

4. Birt, D.F.; Hendrich, S.; Wang, W. Dietary agents in cancer prevention: Flavonoids and isoflavonoids. Pharmacol. Ther. 2001, 90, 157-177. [CrossRef]

5. Varinska, L.; Gal, P.; Mojzisova, G.; Mirossay, L.; Mojzis, J. Soy and breast cancer: Focus on angiogenesis. Int. J. Mol. Sci. 2015, 16, 11728-11749. [CrossRef] [PubMed]

6. Uifălean, A.; Schneider, S.; Gierok, P.; Ionescu, C.; Iuga, C.A.; Lalk, M. The impact of soy isoflavones on MCF-7 and MDA-MB-231 breast cancer cells using a global metabolomic approach. Int. J. Mol. Sci. 2016, 17, 1443. [CrossRef] [PubMed]

7. Siow, R.C.M.; Mann, G.E. Dietary isoflavones and vascular protection: Activation of cellular antioxidant defenses by SERMs or hormesis? Mol. Asp. Med. 2010, 31, 468-477. [CrossRef] [PubMed]

8. Gil-Izquierdo, A.; Penalvo, J.L.; Gil, J.I.; Medina, S.; Horcajada, M.N.; Lafay, S.; Silberberg, M.; Llorach, R.; Zafrilla, P.; Garcia-Mora, P.; et al. Soy isoflavones and cardiovascular disease epidemiological, clinical and -omics perspectives. Curr. Pharm. Biotechnol. 2012, 13, 624-631. [CrossRef] [PubMed]

9. Castelo-Branco, C.; Cancelo Hidalgo, M.J. Isoflavones: Effects on bone health. Climacteric 2011, 14, $204-211$. [CrossRef] [PubMed]

10. Howes, L.G.; Howes, J.B.; Knight, D.C. Isoflavone therapy for menopausal flushes: A systematic review and meta-analysis. Maturitas 2006, 55, 203-211. [CrossRef] [PubMed]

11. Somekawa, Y.; Chiguchi, M.; Ishibashi, T.; Aso, T. Soy intake related to menopausal symptoms, serum lipids, and bone mineral density in postmenopausal Japanese women. Obstet. Gynecol. 2001, 97, 109-115. [CrossRef] [PubMed]

12. Sordon, S.; Popłoński, J.; Huszcza, E. Microbial glycosylation of flavonoids. Pol. J. Microbiol. 2016, 65, $137-151$. [CrossRef]

13. Hollman, P.C.; Bijsman, M.N.; van Gameren, Y.; Cnossen, E.P.; de Vries, J.H.; Katan, M.B. The sugar moiety is a major determinant of the absorption of dietary flavonoid glycosides in man. Free Radic. Res. 1999, 3, 569-573. [CrossRef]

14. Hollman, P.C.; Katan, M.B. Absorption, metabolism and health effects of dietary flavonoids in man. Biomed. Pharmacother. 1997, 51, 305-310. [CrossRef]

15. Piskula, M.K.; Yamakoshi, J.; Iwai, Y. Daidzein and genistein but not their glucosides are absorbed from the rat stomach. FEBS Lett. 1999, 447, 287-291. [CrossRef]

16. Crespy, V.; Morand, C.; Besson, C.; Manach, C.; Demigne, C.; Remesy, C. Quercetin, but not its glycosides, is absorbed from the rat stomach. J. Agric. Food Chem. 2002, 50, 618-621. [CrossRef] [PubMed]

17. Cornard, J.P.; Boudet, A.C.; Merlin, J.C. Theoretical investigation of the molecular structure of the isoquercitrin molecule. J. Mol. Struct. 1999, 508, 37-49. [CrossRef]

18. Wach, A.; Pyrzynska, K.; Biesaga, M. Quercetin content in some food and herbal samples. Food Chem. 2007, 100, 699-704. [CrossRef]

19. Chang, Q.; Zuo, Z.; Chow, M.S.S.; Ho, W.K.K. Difference in absorption of the two structurally similar flavonoid glycosides, hyperoside and isoquercitrin in rats. Eur. J. Pharm. Biopharm. 2005, 59, 549-555. [CrossRef] [PubMed]

20. Izumi, T.; Piskula, M.K.; Osawa, S.; Obata, A.; Tobe, K.; Saito, M.; Kataoka, S.; Kubota, Y.; Kikuchi, M. Soy isoflavone aglycones are absorbed faster and in higher amounts than their glucosides in humans. J. Nutr. 2000, 130, 1695-1699. [PubMed]

21. Setchell, K.D.R.; Brown, N.M.; Desai, P.; Zimmer-Nechemias, L.; Wolfe, B.E.; Brashear, W.T.; Kirschner, A.S.; Cassidy, A.; Heubi, J.E. Bioavailability of pure isoflavones in healthy humans and analysis of commercial soy isoflavone supplements. J. Nutr. 2001, 131, 1362-1375.

22. Bartmańska, A.; Huszcza, E.; Tronina, T. Transformation of isoxanthohumol by fungi. J. Mol. Catal. B Enzym. 2009, 61, 221-224. [CrossRef]

23. Bartmańska, A.; Tronina, T.; Huszcza, E. Transformation of 8-prenylnaringenin by Absidia coerulea and Beauveria bassiana. Bioorg. Med. Chem. Lett. 2012, 22, 6451-6453. [CrossRef] [PubMed]

24. Tronina, T.; Bartmańska, A.; Milczarek, M.; Wietrzyk, J.; Popłoński, J.; Rój, E.; Huszcza, E. Antioxidant and antiproliferative activity of glycosides obtained by biotransformation of xanthohumol. Bioorg. Med. Chem. Lett. 2013, 23, 1957-1960. [CrossRef] [PubMed]

25. Hu, F.L.; He, Y.Q.; Huang, B.; Li, C.R.; Fan, M.Z.; Li, Z.Z. Secondary metabolites in a soybean fermentation broth of Paecilomyces militaris. Food Chem. 2009, 116, 198-201. [CrossRef] 
26. Chu, J.; Wu, X.; Li, B.; He, B. Efficient glucosylation of flavonoids by organic solvent-tolerant Staphylococcus saprophyticus CQ16 in aqueous hydrophilic media. J. Mol. Catal. B Enzym. 2014, 99, 8-13. [CrossRef]

27. Shimoda, K.; Kubota, N.; Hamada, H.; Hamada, H. Synthesis of gentiooligosaccharides of genistein and glycitein and their radical scavenging and anti-allergic activity. Molecules 2011, 16, 4740-4747. [CrossRef]

28. Lewis, P.; Kaltia, S.; Wähälä, K. The phase transfer catalyzed synthesis of isoflavone-O-glucosides. J. Chem. Soc. Perkin Trans. 1 1998, 2481-2484. [CrossRef]

29. Sun, J.; Laval, S.; Yu, B. Glycosylation reactions in the synthesis of flavonoid glycosides. Synthesis 2014, 46, 1030-1045.

30. Hsu, F.L.; Yang, L.M.; Chang, S.F.; Wang, L.H.; Hsu, C.Y.; Liu, P.C.; Lin, S.J. Biotransformation of gallic acid by Beauveria sulfurescens ATCC 7159. Appl. Microbiol. Biotechnol. 2007, 74, 659-666. [CrossRef] [PubMed]

31. Yuan, W.; Wang, P.; Zhang, Z.; Li, S. Glycosylation of (-)-maackiain by Beauveria bassiana and Cunninghamella echinulata var. elegans. Biocatal. Biotransform. 2010, 28, 117-121. [CrossRef]

32. Zhan, J.; Gunatilaka, L. Selective $4^{\prime}-O$-methylglycosylation of the pentahydroxy-flavonoid quercetin by Beauveria bassiana ATCC 7159. Biocatal. Biotransform. 2006, 24, 396-399. [CrossRef]

33. Spagnuolo, P.; Rasini, E.; Luini, A.; Legnaro, M.; Luzzani, M.; Casareto, E.; Carreri, M.; Paracchini, S.; Marino, F.; Cosentino, M. Isoflavone content and estrogenic activity of different batches of red clover (Trifolium pratense L.) extracts: An in vitro study in MCF-7 cells. Fitoterapia 2014, 94, 62-69. [CrossRef] [PubMed]

34. Crozier, A.; del Rio, D.; Clifford, M.N. Bioavailability of dietary flavonoids and phenolic compounds. Mol. Asp. Med. 2010, 31, 446-467. [CrossRef] [PubMed]

35. Moon, Y.; Sagawa, K.; Frederick, K.; Zhang, S.; Morris, M.E. Pharmacokinetics and bioavailability of the isoflavone Biochanin A in rats. AAPS J. 2006, 8, 433-442. [CrossRef] [PubMed]

36. Singh Wahajuddin, S.P. Intravenous pharmacokinetics and oral bioavailability of Biochanin A in female rats. Med. Chem. Res. 2011, 20, 1627-1631. [CrossRef]

37. Han, H.K.; Lee, B.J.; Lee, H.K. Enhanced dissolution and bioavailability of Biochanin A via the preparation of solid dispersion: In vitro and in vivo evaluation. Int. J. Pharm. 2011, 415, 89-94. [CrossRef] [PubMed]

38. Utkina, E.A.; Antoshina, S.V.; Selishcheva, A.A.; Sorokoumova, G.M.; Rogozhkina, E.A.; Shvets, V.I. Isoflavones daidzein and genistein: Preparation by acid hydrolysis of their glycosides and the effect on phospholipid peroxidation. Russ. J. Bioorg. Chem. 2004, 30, 429-435. [CrossRef]

39. Ibrachim, M.; Ambreen, S.; Hussain, A.; Hussain, N.; Imran, M.; Ali, B.; Sumrra, S.; Yousuf, H.M.; Rehmani, F.S. Phytochemical investigation on Eucalyptus globulus Labill. Asian J. Chem. 2014, 26, 1011-1014.

40. Xuan, Q.C.; Huang, R.; Miao, C.P.; Chen, Y.W.; Zhai, Y.Z.; Song, F.; Wang, T.; Wu, S.H. Secondary metabolites of endophytic fungus. Chem. Nat. Compd. 2014, 50, 139-141. [CrossRef]

41. Whitten, P.L.; Kudo, S.; Okubo, K.K. Isoflavonoids. In Handbook of Plant and Fungal Toxicants, 2nd ed.; Felix D’Mello, J.P., Ed.; CRC Press: New York, NY, USA, 1997; p. 124.

42. Ilić, S.B.; Konstantinović, S.S.; Todorović, Z.B. Flavonoids from flower of Linum Capitatum Kit UDC 547.972.2. Ser. Phys. Chem. Technol. 2004, 3, 67-71.

43. Zhao, S.; Zhang, L.; Gao, P.; Shao, Z. Isolation and characterization of the isoflavones from sprouted chickpea seeds. Food Chem. 2009, 114, 869-873. [CrossRef]

Sample Availability: Samples of the compounds daidzein, 4"-O-methyldaidzin, Biochanin A, sissotrin and isosissotrin, 4"-O-methylsissotrin are available from the authors.

(C) 2017 by the authors; licensee MDPI, Basel, Switzerland. This article is an open access article distributed under the terms and conditions of the Creative Commons Attribution (CC-BY) license (http://creativecommons.org/licenses/by/4.0/). 